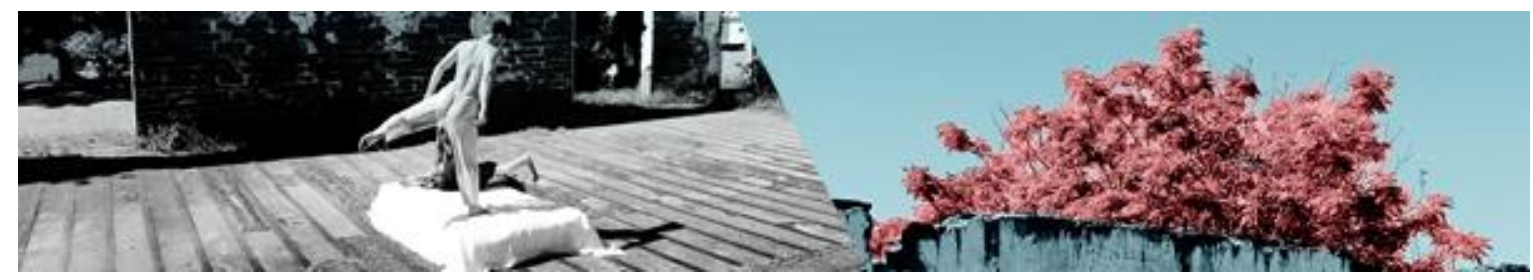

\title{
NA PONTA DOS PÉS: PISANDO EM OVOS OU QUEBRANDO OVOS?
}

\author{
Helena Thofehrn Lessa ${ }^{1}$ \\ Janaina Bruna dos Santos Moreira ${ }^{2}$
}

\begin{abstract}
Resumo: A partir da reflexão sobre uma pesquisa em artes inspirada no feminismo, o texto propõe relações entre a representação das sapatilhas de ponta no balé clássico e seu uso pelas mulheres, resgatando aspectos históricos do balé romântico que contribuíram para que a figura etérea, delicada e leve da bailarina clássica passasse a atravessar o imaginário coletivo. Os processos criativos em dança contemporânea são discutidos como ações políticas para gerar outros modos de relação com as sapatilhas de ponta para quem dança e quem assiste, problematizando as noções sobre o feminino e a mulher propostas aqui como plurais.
\end{abstract}

Palavras-chave: Balé; Mulheres; Feminismo.

\section{ON THE TIPTOE: STEPPING ON EGGS OR BREAKING EGGS?}

\begin{abstract}
From the reflection on a research in arts inspired by feminism, the text proposes relations between the representation of the pointe shoes in the classical ballet and its use by the women, rescuing historical aspects of the romantic ballet that contributed to the ethereal, delicate and light figure of the classical dancer that cross the collective imaginary. The creative processes in contemporary dance are discussed as political actions to generate other modes of relation with the pointe shoes for those who dance and who assists, problematizing the notions about the feminine and the woman proposed here as plurals.
\end{abstract}

Keywords: Ballet; Women; Feminism.

\section{Apresentação da pesquisa}

Talvez tudo se passe em torno destas três perguntas: $O$ que o corpo herda? Como ele herda? Como se posiciona diante do que herda? (ROCHA, 2016, p. 53)

Esses três questionamentos inspiram o presente trabalho porque nos provocam a refletir sobre nossas trajetórias dançantes, sobre o que elas representam para nós e para a sociedade em geral e como nos posicionamos diante dessas representações. Somos duas mulheres com singularidades, mas que

\footnotetext{
'Licenciada em Dança e Fisioterapeuta. Mestra (2014) e Doutora (2018) em Educação Física na Universidade Federal de Pelotas na área de concentração Movimento humano, educação e sociedade - Linha de pesquisa Comportamento Motor. Foi professora substituta auxiliar no curso de Dança - Licenciatura da Universidade Federal de Pelotas e atualmente integra o Grupo de Pesquisa OMEGA - Observatório de Memória, Educação, Gênero e Arte da Universidade Federal de Pelotas.

2 Graduanda no curso de Dança - Licenciatura da Universidade Federal de Pelotas e integrante do Grupo de Pesquisa OMEGA - Observatório de Memória, Educação, Gênero e Arte da Universidade Federal de Pelotas.
}

LESSA, Helena Thofehrn; MOREIRA, Janaina Bruna dos Santos. Na ponta dos pés: pisando em ovos ou quebrando ovos?. Revista da FUNDARTE, Montenegro, p.282-296, ano 19, no 37, Janeiro/Março. Disponível em: http://.seer.fundarte.rs.gov.br/index.php/RevistadaFundarte/index> 30 de março de 2019. 


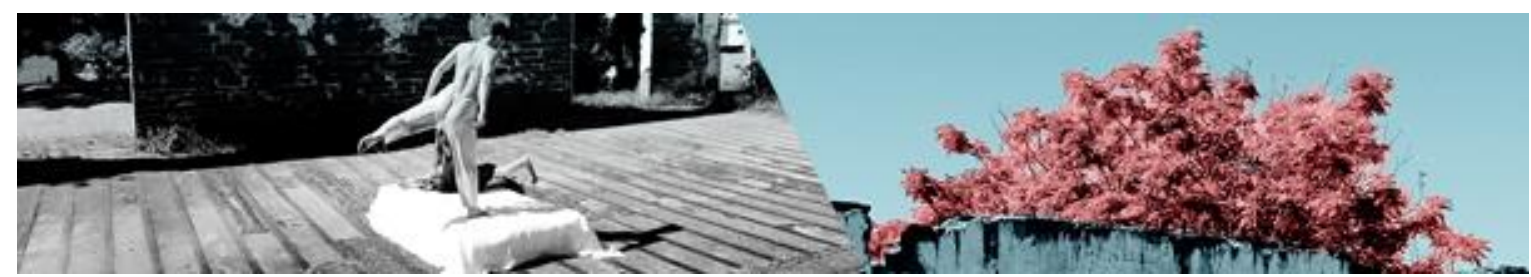

compartilhamos uma experiência comum: a nossa mais extensa experiência em dança, envolvendo a prática por meio de aulas e da cena no balé clássico. Mas, a partir dessa experiência e para além dela, tivemos a vontade de mergulhar no universo da dança contemporânea, principalmente na experimentação e sua relação com diferentes espaços de criação/apresentação.

Essas duas experiências concomitantes geraram provocações e nos convidaram a pensar sobre o papel das mulheres na atualidade e como a dança poderia se configurar como uma possibilidade de ação política no sentido de valorizar e fortalecer as nossas lutas. Esses pensamentos se desdobraram na realização de uma pesquisa em arte (ZAMBONI, 2012) para o trabalho de conclusão do curso de Dança - Licenciatura da Universidade Federal de Pelotas ${ }^{3}$, o qual investigou a forma como os atravessamentos do discurso de agressão às mulheres se articulavam na montagem de uma obra de dança contemporânea.

O referido trabalho artístico, intitulado Nossos Testemunhos, foi composto por cinco cenas e compartilhado com o público no formato de um passeio, que se iniciava no espaço urbano e adentrava um casarão antigo aberto à comunidade na cidade de Pelotas, explorando o seu interior e também a sua área externa. $O$ trabalho teve um caráter de denúncia, visto que o processo criativo se apoiou em imagens, notícias de jornais, dados estatísticos e depoimentos anônimos que traziam informações de agressões contra as mulheres.

Especificamente na última cena do trabalho, intitulada "Semente de sangue" e realizada no pátio do casarão, a intérprete-criadora utilizou sapatilhas de ponta, ali desviadas do seu contexto tradicional ${ }^{4}$, e buscou instigar sensações diversas das que, genericamente, costumamos ter ao apreciar bailarinas clássicas dançando sobre as pontas, as quais normalmente evocam delicadeza e leveza. A cena se passou sobre um linóleo preto estendido no chão, com uma tigela de tinta vermelha fresca em cima. Por meio das sapatilhas de ponta, a intérprete-criadora espalhava a

\footnotetext{
${ }^{3}$ Trabalho de conclusão de curso intitulado "Nossos testemunhos: criar em dança a partir dos discursos sobre violência contra o gênero feminino" com autoria de Janaina Bruna dos Santos Moreira e orientação de Helena Thofehrn Lessa, defendido e aprovado em novembro de 2018.

${ }^{4}$ Aqui estamos nos referindo ao palco italiano e à temática/narrativa do trabalho artístico.

LESSA, Helena Thofehrn; MOREIRA, Janaina Bruna dos Santos. Na ponta dos pés: pisando em ovos ou quebrando ovos?. Revista da FUNDARTE, Montenegro, p.282-296, ano 19, oㅜ 37, Janeiro/Março. Disponível em: http://.seer.fundarte.rs.gov.br/index.php/RevistadaFundarte/index> 30 de março de 2019.
} 


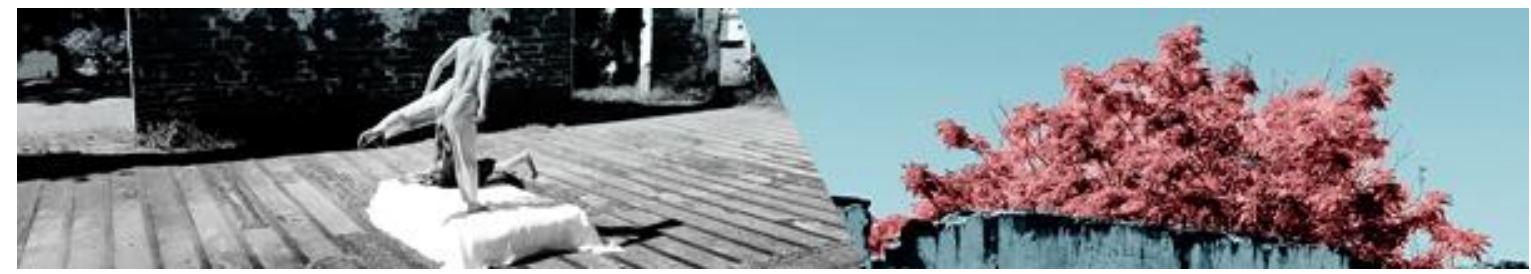

tinta com movimentos fortes carregando consigo as memórias do sangue derramado por mulheres que foram vítimas de agressões cometidas por homens (Figura 1).

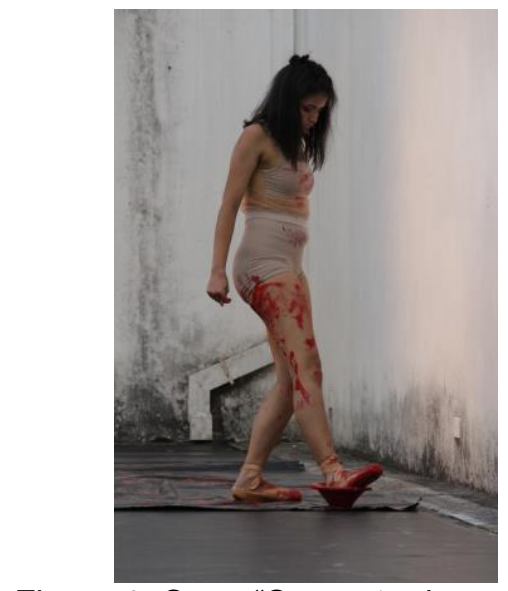

Figura 1: Cena "Semente de sangue".

Fonte: Josiane Franken Corrêa, 2018.

A escolha de usar sapatilhas de ponta nesse trabalho e nessa cena específica se deu, justamente, para gerar um contraponto entre a representação etérea da bailarina que dança na ponta dos pés e que não aparenta fazer esforço algum - dando a impressão de pisar em ovos - e a bailarina que faz questão de mostrar o contrário e que parece não querer vencer a gravidade, dando a impressão de quebrar os ovos. Após a apresentação do trabalho artístico, passamos a nos questionar mais profundamente sobre as relações entre a representação das sapatilhas de ponta no balé clássico e a visão sobre as mulheres; bem como a discutir como os processos criativos em dança contemporânea podem gerar outras possibilidades de experimentação com a sapatilha de ponta e, talvez, outros modos de relação com esse objeto.

A partir dos objetivos expostos, a presente pesquisa seguiu uma abordagem qualitativa (FLORENTINO, 2012) e traçou reflexões a partir de uma pesquisa em Artes que se inspira no feminismo enquanto método, "[... no sentido de caminho que se faz ao caminhar, sem garantia alguma que se chegará ao destino desejado" (TIBURI, 2018, p.44). As reflexões tecidas ao longo do texto se baseiam principalmente nas teorias de: Rengel e Van Langendonck (2006) e Bourcier (2001), para resgatar pontos da história do balé clássico e sua relação com as sapatilhas de ponta; Santos (2009), Ferreira (2016) e Camargo (2017), para discutir as relações 


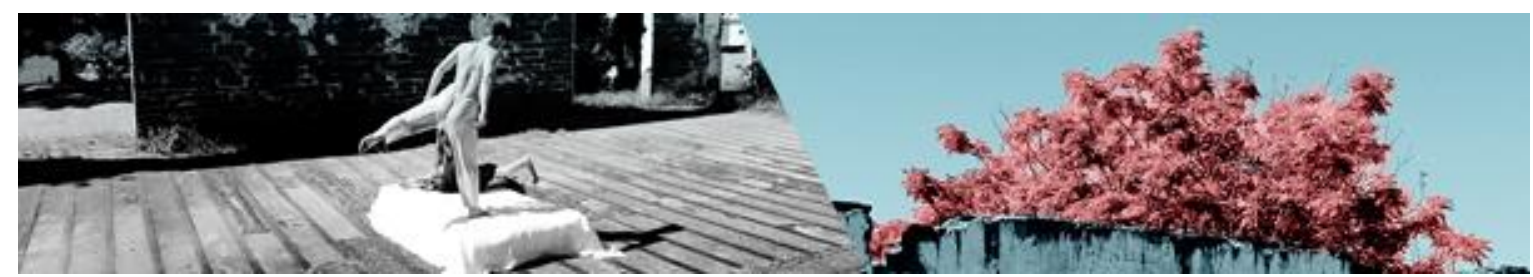

entre a representação da bailarina clássica e as sapatilhas de ponta; Tiburi (2018), para subsidiar nossos pensamentos sobre o feminismo; e Rocha (2016), para nos ajudar a falar sobre corpo(s) e dança(s) contemporânea(s).

\section{Abrindo as cortinas para o processo}

Recorremos à história da dança, mais especificamente ao período que contempla as principais modificações no balé clássico, para relembrar o contexto em que as sapatilhas de ponta surgiram e, neste processo de busca, encontramos o balé romântico. Esse movimento começou na França por volta de 1830 e seus ideais trouxeram grandes modificações para a técnica do balé, dentre elas a introdução das sapatilhas de ponta, as quais "foram criadas para que as bailarinas românticas subissem nas pontas dos pés e aparentassem uma leveza sobrenatural" (RENGEL; VAN LANGENDONCK, 2006, p.33). Em associação a essas sapatilhas, as roupas ficaram cada vez mais leves, permitindo a ilusão do incorpóreo da figura feminina e facilitando a fluidez dos movimentos.

Rengel e Van Langendonck (2006) contam que a primeira bailarina a incorporar sapatilhas de ponta à sua dança foi Marie Taglioni (1804-1884) em 1831, contratada pela Ópera de Paris. O responsável por introduzir as sapatilhas de ponta, assim como outros ideais do romantismo, foi seu pai Felipe Taglioni (1777-1871). O balé romântico buscava exprimir o irreal, criando um novo mundo e fazendo irromper a fantasia e os sentimentos do ser humano. Essas características podem ser percebidas a partir de impressões comentadas por Bourcier (2001, p.202) sobre Marie Taglioni, em que o autor aponta que "os críticos da época descrevem-na dançando na ponta, mal roçando o solo, como um ser imaterial, num estilo 'todo poesia e leveza, graça e suavidade'”.

A partir das características evidenciadas, Santos (2009) discute que as sapatilhas de ponta foram responsáveis não somente por ampliarem a técnica do balé clássico, mas também por expandirem o papel feminino na dança. Foi na época do romantismo que o balé clássico exaltou a mulher, tornando-a o centro das 


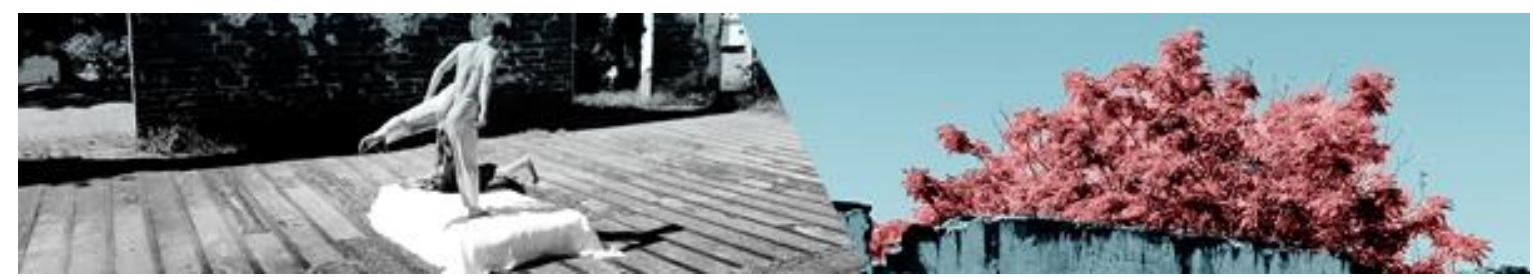

atenções. Desde então, a figura da bailarina foi mitificada sob influência das raízes aristocráticas e dos contos de fadas.

A figura da bailarina clássica que passou a atravessar o imaginário coletivo carregava e ainda carrega "[...] marcas de uma feminilidade idealizada que transcende o campo da dança e é compartilhada por esferas como a família, a mídia e a escola" (SANTOS, 2009, p.88), se estendendo para os livros, filmes e brinquedos. Essas marcas, segundo Santos (2009), podem ser percebidas em características como a postura exigida, o ideal de feminilidade que equipara a beleza e a graça à excessiva magreza, a personalidade predisposta à encarnação de personagens como ninfas, fadas e sílfides, assim como a presença de atributos necessários ao aprendizado de seu ofício, como disciplina, organização, passividade e obediência.

Em cena as bailarinas clássicas não podem revelar a força física necessária para realizar a sua dança leve, e essa característica parece estar contida na técnica do balé, trazendo a estética que Camargo (2017) chama de "estética enganosa do sentido de leveza da bailarina clássica sur la pointe”, já que existe um paradoxo entre as sensações que o uso da sapatilha de ponta provoca em quem dança e em quem assiste o balé clássico enquanto espectador(a).

Quando visualizamos a imagem de uma bailarina clássica sur la pointe não a relacionamos à primeira vista ao sentido de dor, como já narrado, a imagem tem sentido de leveza, desperta o ideal do belo dentro das concepções estabelecidas pelo ballet clássico, seja pelas linhas corpóreas bem alinhadas e bem posicionadas, pelo físico ou pelo domínio técnico. (CAMARGO, 2017, p.125).

Além de elevada exigência física necessária para a apropriação da técnica de pontas, Gonçalves e Vaz (2011, p.91) colocam que a dor também aparece como um elemento configurador dessa rotina por parte das bailarinas, as quais "[...] reagem ao sofrimento de forma aparentemente tranquila, inclusive mantendo o sorriso nos lábios". De fato, enquanto bailarinas clássicas, concordamos com a rotina exposta pelas autoras e chamamos atenção para esse estado desnudo que se opõe ao contexto irreal criado pelos balés românticos e perpetuado pela sociedade.

LESSA, Helena Thofehrn; MOREIRA, Janaina Bruna dos Santos. Na ponta dos pés: pisando em ovos ou quebrando ovos?. Revista da FUNDARTE, Montenegro, p.282-296, ano 19, no 37, Janeiro/Março. Disponível em: http://.seer.fundarte.rs.gov.br/index.php/RevistadaFundarte/index> 30 de março de 2019. 


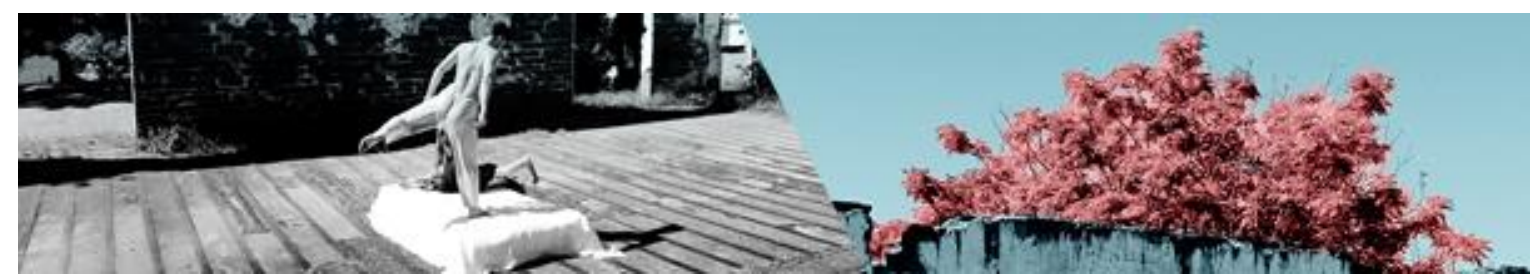

Atentando para esse paradoxo que costuma se manter invisível para quem assiste dança, no ano de 2004 o coreógrafo francês Jerôme Bel ${ }^{5}$ dirigiu a obra Veronique Doisneau, dançada pela bailarina homônima na Ópera Nacional de Paris. Tomando emprestadas as palavras de Ferreira (2016), o trabalho trata de um solo em que o balé clássico é descortinado sob a ótica da bailarina secundária da companhia prestes a se aposentar.

Vestindo roupas de ensaio e carregando uma saia de balé romântico feita de tule, uma garrafa de água e seu par de sapatilhas de ponta, a bailarina inverte a ordem convencional da estrutura clássica e mostra o não visto por meio da sua oralidade e do seu movimento. Além de se apresentar e partilhar informações pessoais com a plateia, Veronique relata sua função no segundo ato do balé de repertório $\mathrm{O}$ Lago dos $\mathrm{Cisnes}^{6}$, em que ela (uma das trinta e duas bailarinas que compõe o cenário humano) faz poses e movimentos de transição enquanto o casal solista dança:

Nas palavras dela: "a coisa mais horrível que fazemos" por causa das dores e câimbras ocasionadas pelas posições estáticas e que percorrem longos oito minutos da coreografia. Forma de aparição que gera um estado de apatia ou mesmo de deslocamento de sua própria presença cênica. Uma espécie de invisibilização. (FERREIRA, 2016, p.767).

Ferreira (2016) acrescenta que Veronique Doisneau não se refere apenas à narração da vida da bailarina que intitula a obra, mas trata de um discurso coletivo que revela o esforço contido nessa trajetória, o qual também é evidenciado pela bailarina quando ela precisa retomar o fôlego para continuar seu diálogo com a plateia, após realizados alguns movimentos. Nesse sentido,

\footnotetext{
${ }^{5}$ Segundo Ferreira (2016), Jérôme Bel é integrante do movimento de dança conceitual surgido na Europa na década de 1990, com Vera Mantero e Xavier Le Roy. O questionamento da exacerbada importância dada ao movimento na dança é um dos aspectos recorrentes dos coreógrafos citados e, em função disso, propõe uma estética do movimento não codificado e políticas de ação para o corpo e a dança.

${ }^{6} \mathrm{O}$ Lago dos Cisnes é um dos maiores clássicos da história da dança. Foi o primeiro balé com música especialmente composta por Tchaikovsky e sua primeira montagem foi realizada no Teatro Bolshoi na Rússia em 1877. A coreografia utiliza cisnes como metáfora dos seres humanos, em que sentimento e natureza viram uma coisa só (BOGÉA, 2007).
}

LESSA, Helena Thofehrn; MOREIRA, Janaina Bruna dos Santos. Na ponta dos pés: pisando em ovos ou quebrando ovos?. Revista da FUNDARTE, Montenegro, p.282-296, ano 19, oㅜ 37, Janeiro/Março. Disponível em: http://.seer.fundarte.rs.gov.br/index.php/RevistadaFundarte/index> 30 de março de 2019. 


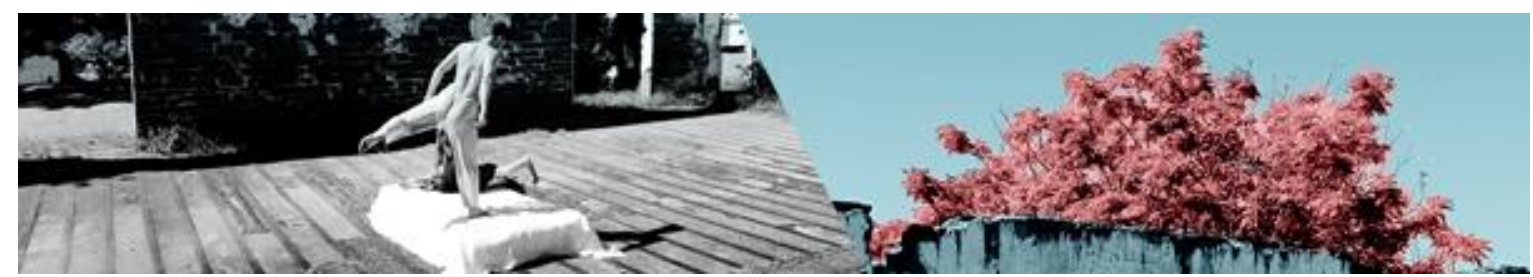

Esta obra desnuda o fato de que o glamour e a delicadeza representados em cena, nos balés de repertório, fazem parte de papéis previamente estabelecidos e lugares instituídos pela tradição artística. A bailarina etérea, que por praticamente dois séculos apareceu desumanizada e romântica, revela sua vulnerabilidade para virar ao avesso o que parecia sublime demais. (FERREIRA, 2016, p.768).

Camargo (2017) destaca que a imagem etérea da bailarina da era romântica pode ter surgido da necessidade da assimilação do feminino como algo ligado a pureza e a beleza. O romantismo foi o período crucial para que o balé clássico se estruturasse nos modelos que o perpetuaram até os dias atuais, mantendo a visualidade imagética da bailarina clássica sobre as pontas e a ideia dos sentidos por ela representados como leveza, beleza e delicadeza.

Ao refletir sobre as possibilidades de entender o feminino e a mulher na dança, entendemos que a leveza, a beleza e a delicadeza são características que podem estar contidas nessas definições, mas se compreendidas como essenciais e dependentes limitam conceitos que são plurais e diversos. Para Tiburi (2018), esse tipo de discurso essencialista que diz "as mulheres são assim, os homens são assado" representa um problema porque pressupõe uma verdade única quando estamos nos referindo a seres humanos que se modificam dinamicamente.

No que consiste ser mulher? Apesar de tantos conselhos e prescrições, podemos compreender a impossibilidade da existência da categoria a mulher, pois essas são plurais e diversas entre si. Admitir essa pluralidade, mais do que uma questão gramatical, representa uma atitude política e epistemológica que fissura a representação em que mulher, dotada de uma essência única e verdadeira, desdobra-se em mulheres, seres localizados em suas especialidades e experiências múltiplas. (SANTOS, 2009, p.69).

Em virtude de conceitos naturalizados na sociedade como homem/mulher e masculino/feminino, o termo gênero ganhou ampla discussão recentemente ${ }^{7}$ e tem sido usado para analisar os papeis "masculino" e "feminino", que se tornaram hegemônicos. Butler (2003) propõe que a aparência de homem e de mulher está bastante ligada a regras de comportamento, as quais acabam por nos controlar socialmente e domesticamente.

\footnotetext{
${ }^{7}$ Para maior aprofundamento sobre as questões de gênero sugerimos a leitura do livro "Problemas de gênero: feminismo e subversão da identidade" de Judith Butler (2003).

LESSA, Helena Thofehrn; MOREIRA, Janaina Bruna dos Santos. Na ponta dos pés: pisando em ovos ou quebrando ovos?. Revista da FUNDARTE, Montenegro, p.282-296, ano 19, no 37, Janeiro/Março. Disponível em: http://.seer.fundarte.rs.gov.br/index.php/RevistadaFundarte/index> 30 de março de 2019.
} 


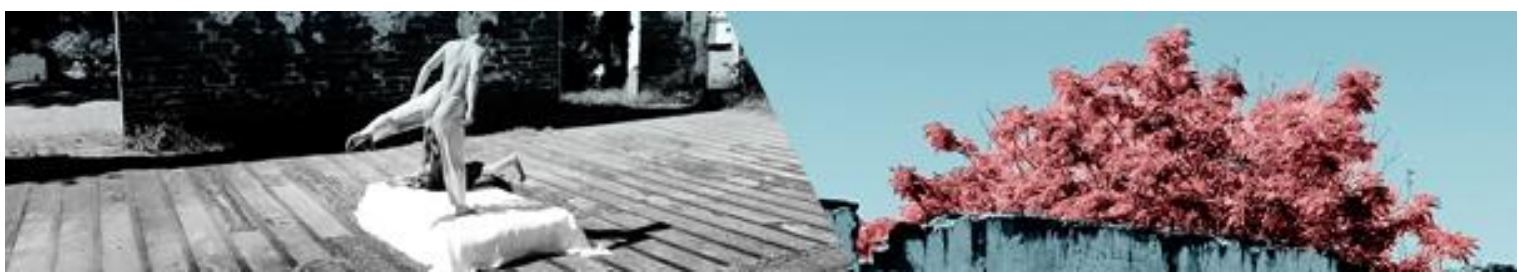

Nesse sentido, a persistência da visão sobre a bailarina clássica que dança sobre as sapatilhas de pontas parece, para além da técnica do gênero de dança em questão, estar amparada pelo sistema que está profundamente enraizado na cultura da sociedade e nas instituições de ensino. Esse sistema, ao qual Tiburi (2018) denomina de patriarcado, se trata de um conjunto de ideias prontas inquestionáveis e certezas naturalizadas que nos são dados, para que orientemos nossas ações de determinado modo que elas possam manter privilégios de gênero, de sexo, de raça, de classe, de idade e de plasticidade, propagando pensamentos que soam bastante limitados, como os de haver uma identidade natural, dois sexos considerados normais, a diferença entre os gêneros, a superioridade masculina e a inferioridade das mulheres.

Diante desse cenário, torna-se inadiável ressignificar o termo mulher construído no patriarcado, buscando assumir as identidades que nos fazem bem, que nos dão sentido e que não podem ser vividas como dívidas. O feminismo, então, entra como a ação que põe em cena o desejo daquelas que, sendo mulheres, no mais amplo sentido dessa palavra, lutam contra a sua docilização (TIBURI, 2018).

\begin{abstract}
Não há nada mais importante na vida do que aprender a pensar, e não se aprende a pensar sem aprender a perguntar pelas condições e pelos contextos nos quais estão situados os nossos objetos de análise e de interesse. A crítica não é necessariamente a destruição daquilo que se quer conhecer. Ela pode ser uma desmontagem organizada que permite a reconstrução do objeto anteriormente desmontado. Ela pode ser também uma atenção especial que damos às coisas e ao nosso próprio modo de pensar, que vem melhorar o nosso olhar. Toda forma de crítica, desde que seja honesta, é válida, mas considero que nesse último sentido, como atenção cuidadosa, é possível seguir aproveitando ao máximo as potências do pensamento que visa à transformação do mundo ao qual o feminismo, como ética-política, necessariamente se liga. (TIBURI, 2018, p.10).
\end{abstract}

Acreditamos que com o interesse direcionado à pluralidade do que é ser mulher, bem como ao olhar independente entre ser mulher e as características de comportamento denominadas femininas, a dança pode ser explorada como uma possibilidade de expressão e luta contra o patriarcado. Por que somente a sensação de acomodação na sapatilha de ponta é aproveitada e valorizada? Por que não pensar em descortinar mais o processo como fez Jerôme Bel em Veronique 


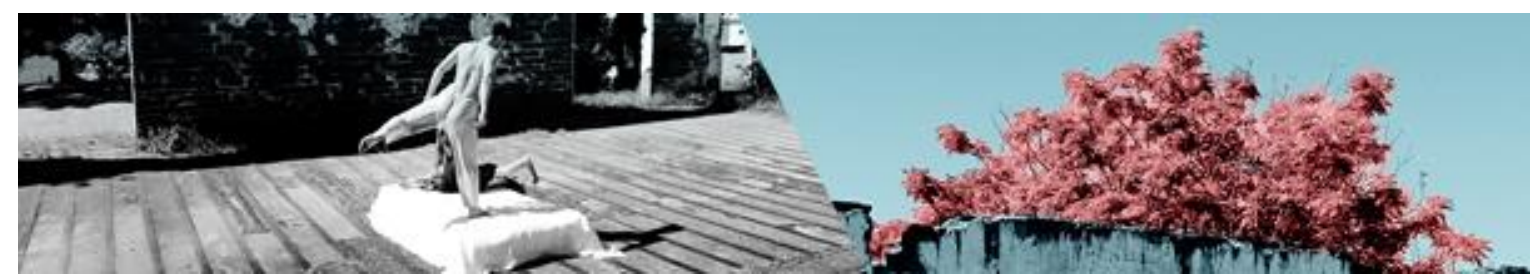

Doisneau? Se pensadas em outro espaço/contexto, as sapatilhas de ponta podem colocar em jogo as representações que elas trazem para as mulheres?

\title{
Semente de sangue: espalhando possibilidades
}

Ao entender a dança contemporânea como uma pergunta que o corpo se faz, Rocha (2016, p.114) coloca que "Se na dança contemporânea é a própria dança que faz perguntas a si e ao mundo, ela pode se oferecer como um bom operador transversal para pensar qualquer dança". Enquanto projeto coreográfico contemporâneo, Nossos Testemunhos se propôs a trazer à tona a violência contra as mulheres para a criação coreográfica como forma de colaborar e fortalecer o nosso movimento político. O trabalho se voltou, também, para a hibridação dos corpos, os quais buscam cada vez mais versatilidade e disponibilidade no mundo. São corpos que, mesmo especializados em alguma prática, são plurais por conta de seus atravessamentos e suas vivências. A autora Louppe (2000, p.31) aponta que:

\begin{abstract}
A hibridação é, hoje em dia, o destino do corpo que dança, um resultado tanto das exigências da criação coreográfica, como da elaboração de sua própria formação. A elaboração de zonas reconhecíveis da experiência corporal e a construção do sujeito através de uma determinada prática corporal tornam-se, então, quase impossíveis.
\end{abstract}

Rocha (2016) acrescenta que a hibridação é uma soma de perdas. Não existe exatamente a fusão de dois ou mais termos de partida porque há perdas no processo, gerando um terceiro campo que não necessariamente coincide de todo com cada um dos termos de onde partiu. A cena "Semente de sangue" do Nossos Testemunhos carrega esses traços de hibridação ao deslocar o uso das sapatilhas de ponta para um contexto diverso e trazer outros atravessamentos que se cruzam com ele, como o de uma mulher feminista dançando na rua. Há, portanto, a união e a perda entre a prática do balé clássico e as demais experiências (de vida) em dança, que hibridizam o corpo da intérprete-criadora.

A cena inicia quando a intérprete-criadora, de pés descalços, recolhe suas sapatilhas de ponta, encontradas próximas aos arcos que arquitetam o espaço, e senta para calçá-las de frente para o público (Figura 2). Esse momento faz parte da

LESSA, Helena Thofehrn; MOREIRA, Janaina Bruna dos Santos. Na ponta dos pés: pisando em ovos ou quebrando ovos?. Revista da FUNDARTE, Montenegro, p.282-296, ano 19, no 37, Janeiro/Março. Disponível em: http://.seer.fundarte.rs.gov.br/index.php/RevistadaFundarte/index> 30 de março de 2019. 


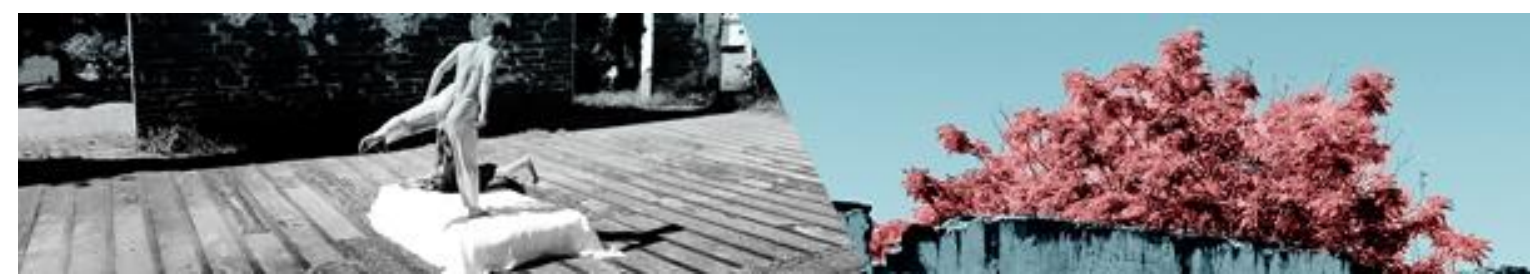

rotina das bailarinas clássicas e é bastante simbólico no universo desse gênero de dança, denotando concentração e preparação dos pés com a utilização de materiais para proteger os dedos, como esparadrapos e ponteiras confeccionadas normalmente de pano ou silicone.

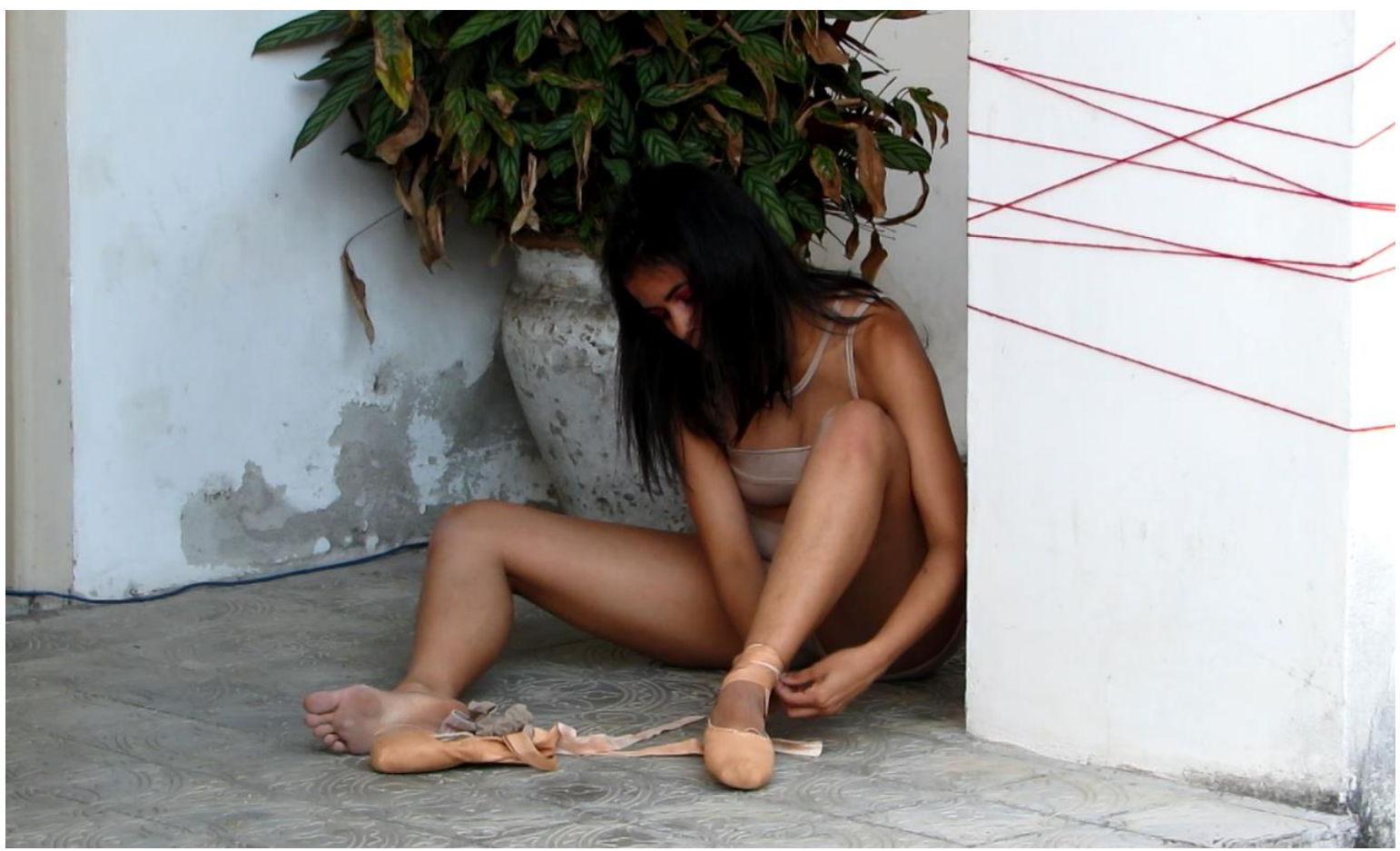

Figura 2: Momento da cena em que a intérprete-criadora calça suas sapatilhas de ponta. Fonte: Marcelo Tempel Stumpf, 2018.

A seguir, a intérprete-criadora se põe em pé. Alguns movimentos leves, como se estivesse acomodando seus pés e seu eixo corporal sobre as sapatilhas de ponta recém calçadas, são realizados para se direcionar ao espaço onde se encontra no chão o linóleo com uma tigela de tinta vermelha; tinta que representa o sangue: o seu, o nosso, e que se unem ao da intérprete-criadora (Figura 3).

LESSA, Helena Thofehrn; MOREIRA, Janaina Bruna dos Santos. Na ponta dos pés: pisando em ovos ou quebrando ovos?. Revista da FUNDARTE, Montenegro, p.282-296, ano 19, oㅜ 37, Janeiro/Março. Disponível em: http://.seer.fundarte.rs.gov.br/index.php/RevistadaFundarte/index> 30 de março de 2019. 

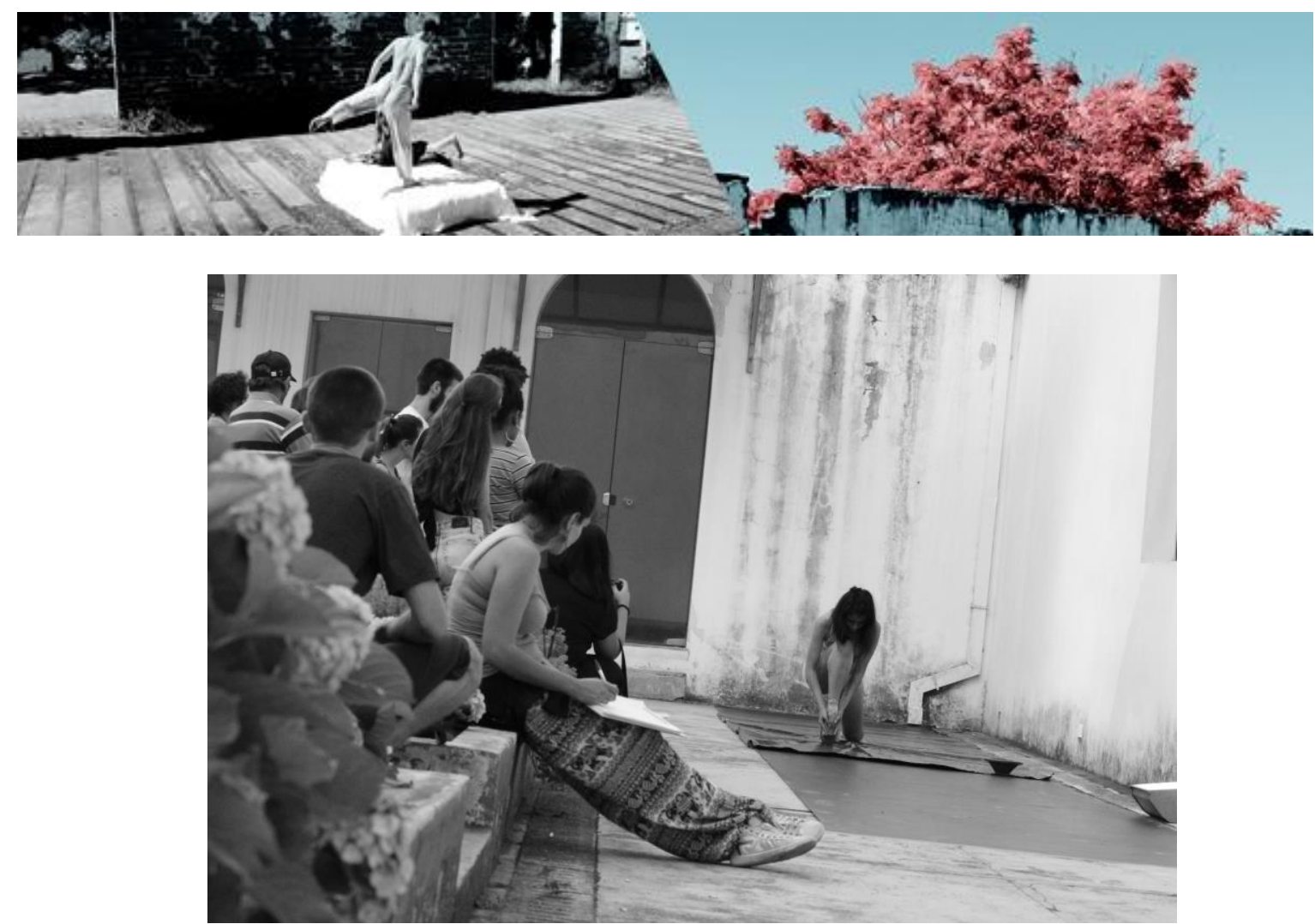

Figura 3: Contexto da cena.

Fonte: Josiane Franken Corrêa, 2018.

Partes do corpo da intérprete-criadora são mergulhadas naquela representação de sangue e, principalmente por meio das sapatilhas de ponta, a tinta começa a ser espalhada pelo espaço. A partir do contato com aquela textura, movimentos fortes surgem e também as mãos são mergulhadas na tinta, pensando nas ligações que realiza com o tema da agressão contra as mulheres. Logo o sangue já está pelo corpo todo, o sangue das mulheres que morre(ra)m para que a intérprete-criadora pudesse estar ali, para poder pensar/vestir-se/agir como quer. Não há música para essa cena; os sons são alguns suspiros/respiros emitidos pela intérprete-criadora, bem como o roçar da ponta rígida da sapatilha espalhando a tinta no chão.

A partir da descrição da cena, percebemos as possibilidades políticas pela presença de diferentes aspectos: 1) pelo uso das sapatilhas de ponta no pátio de um casarão aberto à comunidade e não em um palco onde normalmente costumam ser apresentadas as montagens de balés de repertório devido à estrutura necessária; 2) por se tratar de uma mulher dançando que, por meio dessa sua dança, denuncia a agressão que ela e outras mulheres sofre(ra)m nos seus cotidianos; 3) pelo fato de a intérprete-criadora ser uma mulher feminista dançando sozinha na rua.

Partindo da noção de que "Sem predicado, o corpo é uma política" (ROCHA, 2016, p.30), no momento em que pensamos nessas três razões juntas, já que é 


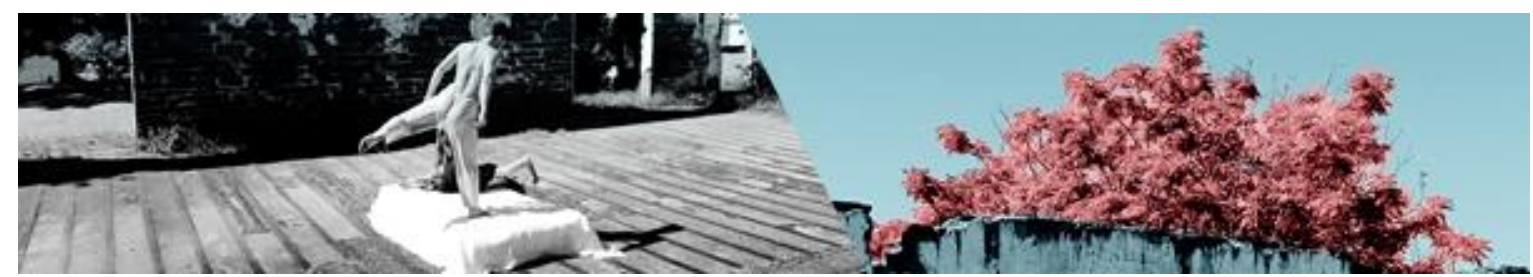

assim que elas acontecem em cena, somamos representações e acreditamos que a possibilidade política ganha força. No entanto, cabe salientar que, após a apresentação do trabalho, uma das espectadoras veio conversar conosco e comentou: "confesso que não tinha compreendido a presença da sapatilha de ponta e seu espalhar vermelho, mas depois da fala da bailarina, eu entendi”.

O comentário chamou nossa atenção para a força que a representação da sapatilha de ponta possui; mesmo deslocada de seu contexto comum ela parece evocar leveza e delicadeza, parecendo não condizer com a cena em questão. Ali a intérprete-criadora não vestia saia de tule, não dançava sobre um palco, não usava música e não dançava uma composição de balé de repertório. Ainda, todo o contexto da proposta coreográfica estava direcionado para a temática da agressão contra as mulheres.

Além de esse acontecimento reiterar que "o espectador vai ver o que o espectador vai ver" (ROCHA, 2016, p.92), não existindo a possibilidade de estabelecer uma relação entre causa e efeito com a proposta coreográfica, ele nos atentou para a importância de discutirmos mais sobre a representação da sapatilha de ponta, de valorizar mais o processo no balé clássico e de propor mais deslocamentos coreográficos como esse para que as pessoas possam ser provocadas a se questionar. Afinal, "a dança contemporânea ainda e sempre não decidiu o que a dança é e, assim, o que ela deve ser" (ROCHA, 2016, p.94).

Excedendo os deslocamentos no campo da criação e da dança contemporânea, acreditamos que esses deslocamentos podem se dar também no campo da relação criada com a sapatilha de ponta. Convidamos outras bailarinas clássicas mulheres, como nós, a refletirem sobre as representações desse objeto para si, entendendo que:

[...] o feminismo nos dá uma biografia. Ele é a narrativa de si, autoavaliação crítica e autocrítica das mulheres. A narrativa daquelas pessoas que não tiveram narrativa, que não tiveram direito de uma história. Por meio dessa história que vem sendo construída e que tem um longo caminho pela frente, o feminismo nos dá a chance de nos devolver ao nosso tempo, aos nossos pensamentos, ao nosso corpo. (TIBURI, 2018, p.103).

Reticências.

LESSA, Helena Thofehrn; MOREIRA, Janaina Bruna dos Santos. Na ponta dos pés: pisando em ovos ou quebrando ovos?. Revista da FUNDARTE, Montenegro, p.282-296, ano 19, no 37, Janeiro/Março. Disponível em: http://.seer.fundarte.rs.gov.br/index.php/RevistadaFundarte/index> 30 de março de 2019. 


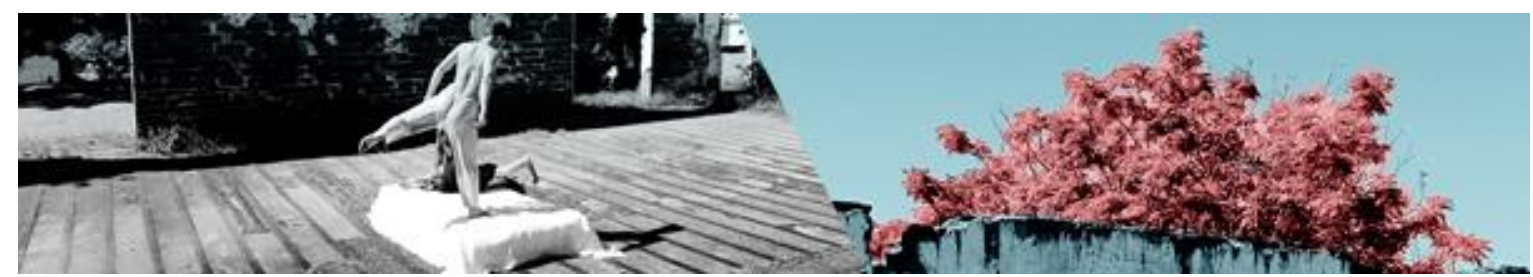

\section{Considerações finais}

As reflexões trazidas partiram de uma pesquisa em Artes, o que nos permite afirmar que o processo nos provocou e nos moveu até mesmo quando achávamos que ele já havia chegado ao fim. Nesse ponto, concordamos com Zamboni (2012, p.56) quando o autor diz que "O processo de trabalho, principalmente em arte, não é algo linear, é um processo de idas e vindas, de intuição e de racionalidade que se interpõem no caminho da reconstrução representativa de uma realidade."

O texto aponta para a possibilidade de refletirmos e ressignificarmos nossas (an)danças, questionando e atentando para diferentes olhares sobre a bailarina clássica mulher que dança sobre as sapatilhas de ponta. Ao final dessa reflexão, entendemos que essa ressignificação não pode estar limitada ao binarismo tão presente na sociedade. Ou seja, não existem apenas duas possibilidades de representação por meio das sapatilhas de ponta.

A expressão "quebrar os ovos" foi usada para se referir à cena "Semente de sangue" porque ela buscou denunciar agressões contra as mulheres. Já o "pisar em ovos" foi a metáfora usada para se referir à técnica do balé clássico pelo fato de que as bailarinas não podem descer e subir das pontas dos pés aos solavancos, mas devem exercer demasiada força para que essas etapas pareçam suaves enquanto estão dançando. Trouxemos as duas expressões porque se contrapõem, mas entendemos que as possibilidades são múltiplas e que interessa compreender o contexto em que a proposta coreográfica está inserida.

Sobre esse ponto, interessa saber que é preciso quebrar muitos ovos para conseguir apenas pisar sobre eles. Nesse sentido, gostaríamos de atentar para a maior valorização do processo no universo do balé clássico, como fez Jerôme Bel com Veronique Doisneau, por exemplo. Talvez propagando o conhecimento e a valorização do percurso para a apropriação da técnica de pontas, o uso das sapatilhas pode colocar em jogo as representações que elas trazem para as mulheres. Convidamos artistas de forma geral a refletirem sobre as representações e questões trazidas aqui. 


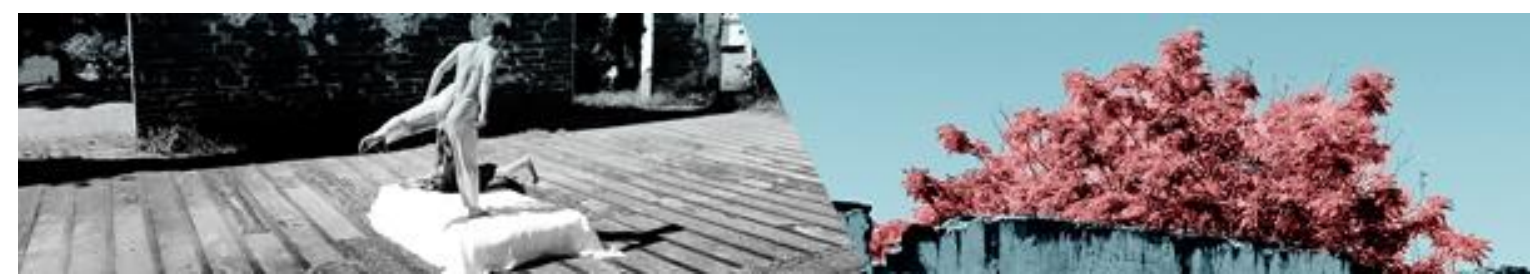

\section{Referências:}

BOGÉA, Inês. Contos do balé. São Paulo: Cosac Naify, 2007.

BOURCIER, Paul. História da dança no ocidente. São Paulo: Martins Fontes, 2001.

BUTLER, Judith. Problemas de gênero: feminismo e subversão da identidade. Rio de Janeiro: Civilização Brasileira, 2003.

CAMARGO, Henrique. Por uma visualidade do ballet clássico: entrecruzamentos entre os sentidos das imagens do corpo na historiografia e na prática do ballet clássico. 2017. 181 f. Dissertação (Mestrado em Arte e Cultura visual) - Universidade Federal de Goiás, Goiânia, 2017. Disponível em: https://repositorio.bc.ufg.br/tede/handle/tede/8252. Acesso em 18 jan. 2018.

FERREIRA, Rousejanny da Silva. Quando o balé fala de si mesmo: o suspiro de Veronique Doisneau. Anais do IV Congresso Nacional de Pesquisadores em Dança. Goiânia: ANDA, 2016. p. 763-770. Disponível em: http://www.portalanda.org.br/anaisarquivos/6-2016-1.pdf. Acesso em 28 jan. 2018.

FLORENTINO, Adilson. A pesquisa qualitativa em artes cênicas: romper os fios, desarmar as tramas. In: Narciso Telles. (Org). Pesquisa em artes cênicas. 1 ed. Rio de Janeiro: E-papers, 2012, v. 01, p. 05-138.

GONÇALVES, Michelle Carreirão; VAZ, Alexandre Fernandez. Dor, domínio do corpo, conformações subjetivas: um estudo sobre o balé. Impulso, v.21, n.51, p.8595, 2011. Disponível em: https://www.metodista.br/revistas/revistasunimep/index.php/impulso/article/view/675/543. Acesso em 27 dez. 2018.

LOUPPE, Laurence. Corpos híbridos. Tradução de Gustavo Ciríaco. In: ANTUNES, Arnaldo... [et al] Lições de Dança 2. Rio de Janeiro: UniverCidade, 2000. p. 27-40.

RENGEL, Lenira; VAN LANGENDONCK, Rosana. Pequena viagem pelo mundo da dança. São Paulo: Moderna, 2006.

ROCHA, Thereza. O que é dança contemporânea?: uma aprendizagem e um livro de saberes. Salvador: Conexões Criativas, 2016.

SANTOS, Tatiana Mielczarski. Entre pedaços de algodão e bailarinas de porcelana: a performance artística do balé clássico como performance de gênero. 2009. 95 f. Dissertação (Mestrado em Educação) - Universidade Federal do Rio Grande do Sul, Porto Alegre, 2009. Disponível em: https://lume.ufrgs.br/handle/10183/21386. Acesso em 27 dez. 2018.

TIBURI, Marcia. Feminismo em comum: para todas, todes e todos. Rio de Janeiro: Rosa dos Tempos, 2018. 


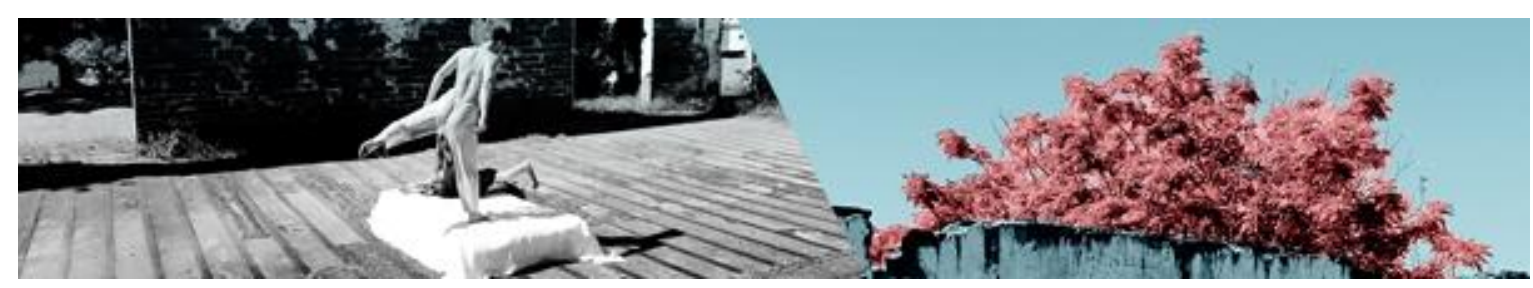

ZAMBONI, Sílvio. A pesquisa em Arte: um paralelo entre arte e ciência. Campinas: Autores Associados, 2012.

LESSA, Helena Thofehrn; MOREIRA, Janaina Bruna dos Santos. Na ponta dos pés: pisando em ovos ou quebrando ovos?. Revista da FUNDARTE, Montenegro, p.282-296, ano 19, nำ37, Janeiro/Março. Disponível em: http://.seer.fundarte.rs.gov.br/index.php/RevistadaFundarte/index> 30 de março de 2019. 